\title{
Soil microbial functionality in response to dairy sewage sludge and mineral fertilisers application under winter rape
}

\author{
K. Oszust ${ }^{1}$ M. Frąc ${ }^{1} \cdot$ J. Lipiec ${ }^{1}$
}

Received: 30 April 2014/Revised: 12 February 2015/Accepted: 17 March 2015/Published online: 9 April 2015

(C) The Author(s) 2015. This article is published with open access at Springerlink.com

\begin{abstract}
Microbial activity and the diversity of their catabolic potential would be stratified according to soil profile as a result of differing content of soil organic $\mathrm{C}$ and they would be altered by applying dairy sewage sludge (DSS) to the surface and subsequently ploughing. We applied $26 \mathrm{Mg} \mathrm{ha}^{-1}$ of DSS and the same nutrient dose of mineral fertilisers as an NPK reference to the soil before sowing winter rape (Brassica napus) in the field experiment. We evaluated the impact of the fertilisers on microbial activity, measured with dehydrogenase and respiratory activity, and diversity of the microbes' catabolic potential from non-rhizosphere and rhizosphere soil at selected depths. In the surface rhizosphere soil, there were significant increases in microbial catabolic potential $(>25 \%)$ and respiratory activity $(>20 \%)$ due to DSS application. All of the microbial parameter values in nonrhizosphere soil were higher at 0-20 than at $25-30 \mathrm{~cm}$. These results are important for improving the management approach of diary sewage sludge application to agricultural soils in the context of increasing microbial activity in the soil profile and reducing mineral fertiliser use.
\end{abstract}

Keywords Catabolic potential · Community-level physiological profiles (CLPPs) - Organic waste $\cdot$ Microbial diversity

M. Frąc

m.frac@ipan.lublin.pl

1 Institute of Agrophysics, Polish Academy of Sciences, P.O. Box 201, 20-290 Lublin, Poland

\section{Introduction}

In the specific case of dairy sewage sludge (DSS) use in agriculture, the positions adopted by farmers organisations have been quite different from one country to another in the recent years. However, their motivations and constraints are in many cases similar. For farmers, the main motivations regarding sludge use in agriculture are the supply of organic fertiliser at low cost. It is therefore possible to say that the farming community's attitude towards sludge recycling through land spreading has recently been strongly influenced by the following factors: the attitude of food industries, food retailers and other customers, the political context and the uncertainty concerning risk. Nevertheless, competition with mineral fertilisers is also a significant factor in countries where agriculture is intensive, as it requires the use of effective fertilisers, since there are growing well-known threat regarding the environmental consequences of using mineral fertilisers in crop production. The problem of inorganic fertilisers application is quite complex, since interrelaces such negative processes as soil degradation, desertification, erosion, and accelerated greenhouse effects and climate change (Diacono and Montemurro 2010). These concerns are likely to be increased in the near future along with the cost of fertilisers.

According to Khaliq et al. (2006), the field application of organic amendments can result in the same crop production with less, or even without, fossil-fuel-based inorganic fertilisers. Therefore, they are increasingly considered as a suitable alternative for mineral one. Organic amendments can serve as carbon additives (Gomez et al. 2004), simultaneously providing nutrient supplements that are easily changed and cycled by microbiota (Schutter and Dick 2001). Therefore, organic amendments are believed to improve soil structure and thus constitute an 
integral tool for sustainable agriculture (Lal 2009; Bieganowski et al. 2012) which favours microbial biodiversity and activity (Gomez et al. 2006; Mikosz 2014) and promotes long-term fertility and productivity.

Field application of DSS, among other organic amendments, can serve for improving and subsequently maintaining soil properties on proper level. It occurs with addition of exogenous organic matter into the soil, containing an opulence of microbial diversity which is able to positively change the soil fertility and thus plant production (Zhu et al. 2014). On the other hand, DSS does not pose a threat to crops because of its low content of heavy metals (Frạc et al. 2012), pathogenic bacteria, viruses, parasites and also toxic organic compounds (Antonijevic and Maric 2008; Pascual et al. 2008; Singh and Agrawal 2008; Jezierska-Tys and Frac 2009). Thus, application of DSS into the field is regarded as proper disposal alternatives (Wang et al. 2008; Frạc and Jezierska-Tys 2011, Gryta et al. 2014), especially in view of the size and growth of the dairy industry and the associated production of large quantities of sewage sludge. Addition of exogenous organic matter to the cropland can lead to an improvement in soil biological functions, depending on the quantity and quality of materials applied. In fact, many effects, e.g. release of nutrients, carbon sequestration, evolve slowly; however, as revised by Diacono and Montemurro (2010), dairy sewage compost soil additives are more probable to maintain $\mathrm{N}$ supply to the plants through continuous mineralisation, comparing to the other organic fertilisers. Moreover, the authors stayed that the dairy-waste compost increased organic carbon content, as compared with other organic treatments, applied at the same available $\mathrm{N}$ level.

However, the main economic driver has led to increase awareness of the importance sludge quality control and of improving land spreading processes, by monitoring the soil properties. Even though there are many related reports recently on sewage sludge application into the soil which take into account soil quality, there are no studies based on a concept of the degree of stratification of soil organic C and $\mathrm{N}$ pools and indirectly microbial functional diversity with soil depth, expressed as a ratio. This approach could indicate soil quality or soil ecosystem functioning even better, because surface organic matter is essential to erosion control, water infiltration and conservation of nutrients. Stratification ratios allow a wide diversity of soils to be compared on the same assessment scale because of an internal normalisation procedure that accounts for inherent soil differences (Franzluebbers 2002).

Microbial communities can exert marked effects on the soil environment and have therefore been promoted as an appropriate tool for understanding ecological management dependency (Ascher et al. 2009). Soil microorganisms respond rapidly to changing conditions by altering their metabolic growth, which allows the comprehensive study of community interactions (Chaparro et al. 2012). Thus, it is important to monitor the changes in microbial diversity, which is very sensitive indicator of soil quality and health (Chen et al. 2012). In addition, soil enzymes are closely related to changes in microbial abundance (Ascher et al. 2009). Therefore, community-level physiological profiling (CLPP), which was later developed for environmental applications (EcoPlates ${ }^{\circledR}$ ), is considered as a type of "enzyme assay" (Qin et al. 2014). This approach has been demonstrated to be a highly sensitive indicator of common environmental and anthropogenic soil modifications (Murugan et al. 2014). CLPP is regarded as a sensor of the biological status of a particular site, because it is based on a metabolic trait. The CLPP approach provides an exciting opportunity to elucidate the functionality of microbes in certain environments, especially to estimate the effects of modern waste management on biological parameters of the soil (Frąc 2012; Williams et al. 2014). Microecology can offer insights into soil depth by revealing factors that maintain and regulate soil functionality and uncovering how the distribution of soil microorganisms influences plant growth (Ettema and Wardle 2002). At smaller scales, the stratified pattern of the microbial decomposers in the soil matrix can influence soil fertility and thus the growth of individual plants. According to Franzluebbers (2002), for a given attribute of the soil ecosystem (soil organic matter, for instance), the stratification indices allow a wide diversity of soils to be compared on the same assessment scales.

Organic matter is physically protected in soil, and quantities of easily decomposable compounds can therefore be found in the vicinity of starving microbial populations that are unable to access them (Schimel and Schaeffer 2012). Substrates, even at distances of micrometres or less, can be unavailable to microorganisms. Organic materials might not be attainable for decomposition due to adsorption on clay minerals and other surfaces or because they are trapped in pores or aggregates (Raynaud and Nunan 2014). In this study, we investigated whether the organic matter, which was incorporated into the soil through DSS addition, is an easily accessible substrate which increases microbial fertility and how DSS fulfils the principles of sustainable development. Soil organic matter plays an important role in long-term soil conservation and restoration by sustaining its fertility, and hence in sustainable agricultural production, due to the improvement of physical, chemical and biological/microbiological properties of soils. To depict the changes in depth-related microbial functional heterogeneity, induced by sludge and mineral fertilizers, the proposed treatments were subjected to carbon source profiling. 
Our previous studies showed that DSS could stimulate microbial activity under winter wheat at $0-20 \mathrm{~cm}$. In this study, the impact of such waste on soil microbial activity and functional diversity is evaluated via investigating the deeper soil layer $(25-30 \mathrm{~cm})$ and rhizosphere soil under winter rape. The purpose of this study is to provide useful information for understanding the changes in microbial functional diversity in rhizosphere and non-rhizosphere soil under winter rape. The objective of this study was to assess how microbial activity and the diversity in catabolic potential of surface rhizosphere soil and surface and subsurface non-rhizosphere soils responded to the application of DSS and mineral fertilisers in the context of rape cultivation. We hypothesised that microbial activity and the diversity in catabolic potential would be stratified in the soil profile as a result of soil organic $\mathrm{C}$ content and that they may be controlled by the surface application of DSS and subsequent ploughing.

\section{Study area}

The field experiment was set up in 2010 on an Eutric Cambisol developed from loess. The experimental plots were located near a dairy sewage treatment plant in Krasnystaw, south-east Poland $\left(50^{\circ} 59^{\prime} 4^{\prime \prime} \mathrm{N}, 23^{\circ} 8^{\prime} 5^{\prime \prime} \mathrm{E}\right)$. The experiment was established in an agricultural field that had been under cultivation for at least the past 50 years, with a crop rotation including selected cereals, root crops and papilionaceous crops. The provided treatments were as follows: DSS - sludge (26 $\mathrm{Mg} \mathrm{ha}^{-1}$ ) with addition of $\mathrm{K}$ $\left(110 \mathrm{~kg} \mathrm{ha}^{-1}\right)$ to introduce the same amount of $\mathrm{K}$ as in mineral fertilisation treatment; mineral fertilisation (MF) $\mathrm{N}\left(170 \mathrm{~kg} \mathrm{ha}^{-1}\right) ; \mathrm{P}\left(100 \mathrm{~kg} \mathrm{ha}^{-1}\right) ; \mathrm{K}\left(160 \mathrm{~kg} \mathrm{ha}^{-1}\right)$; and control (C) - no amendments. The research area has rather uniform soils with respect to genesis and textural composition (clay, silt, sand-450, 470 and $80 \mathrm{~g} \mathrm{~kg}^{-1}$, respectively).

\section{Materials and methods}

The chemical characteristics of the soil were as follows: $\mathrm{pH}$ $6.40, \mathrm{C} / \mathrm{N}-8.30, \mathrm{C}_{\mathrm{tot}}-13.28 \mathrm{~g} \mathrm{~kg}^{-1} \mathrm{DW}, \mathrm{N}_{\text {tot }}-1.60 \mathrm{~g}$ $\mathrm{kg}^{-1} \mathrm{DW}, \mathrm{P}_{\text {tot }}-18.30 \mathrm{~g} \mathrm{~kg}^{-1} \mathrm{DW}, \mathrm{K}_{\mathrm{tot}}-36.80 \mathrm{~g} \mathrm{~kg}^{-1}$ $\mathrm{DW}$. Content of heavy metals $(\mathrm{Pb}, \mathrm{Cu}, \mathrm{Cr})$ was below EU toxicity thresholds.

The main characteristics of the DSS were as follows: $\mathrm{pH}$ 7.23, $\mathrm{C}_{\text {tot }}-868.00 \mathrm{~g} \mathrm{~kg}^{-1} \mathrm{DW}, \mathrm{N}_{\text {tot }}-54.40 \mathrm{~g} \mathrm{~kg}^{-1} \mathrm{dwt}$, $\mathrm{P}_{\text {tot }}-33.00 \mathrm{~g} \mathrm{~kg}^{-1} \mathrm{DW}, \mathrm{K}_{\mathrm{tot}}-15.60 \mathrm{~g} \mathrm{~kg}^{-1} \mathrm{DW}$, dry matter content $-121.30 \mathrm{~g} \mathrm{~kg}^{-1}$. The heavy metal contents were less than the EU values for harmful effects. The DSS and mineral fertilisation (MF) were applied on the soil surface and then ploughed to a depth of $30 \mathrm{~cm}$ before the sowing of winter rape (on 21 August 2010). The planting density of winter rape was $2.8 \mathrm{~kg} \mathrm{ha}^{-1}$. Winter wheat was planted before winter rape at field study. The experiment was set up using a completely randomised block method (RCBD) with three replications. The plot size was $16 \mathrm{~m}^{2}$ $(4 \mathrm{~m} \times 4 \mathrm{~m})$. Each plot was separated from the others by a corridor with $1 \mathrm{~m}$ width. Additionally, soil samples were collected at the distance of $50 \mathrm{~cm}$ from each edge of the plots in order to eliminate the edge effect. Soil samples were collected after two-season planting of winter rape. Soil sampling after the rape harvest was performed as follows:

- 0-20 cm-surface non-rhizosphere soil (SNRH),

- 0-20 cm-surface rhizosphere soil (SRH),

- 25-30 cm-subsurface non-rhizosphere soil (SBNRH).

Rhizosphere soil was regarded in this study as the soil zone in which the environment for microbial activity is influenced by any root growing in it directly (1-5 mm from the external root surface). Non-rhizosphere soil, in turn regards bulk zone, which is normally influenced by growing roots (Oszust et al. 2014).

The soil samples were sieved with a 2-mm mesh and then used for Biolog ${ }^{\circledR}$ microtiter EcoPlates (Hayward, USA) and other analyses. Before sieving, all debris and plant remains were removed to avoid their influence on the measured parameters. For each sampling period, eight subsamples per plot were randomly collected from two soil layers, 0-20 cm and 25-30 cm, with hand-driven probes (10 cm diameter) and then mixed into a single sample per plot. Before microbial analyses, soil samples were stored at $4{ }^{\circ} \mathrm{C}$.

\section{Chemical analysis}

The methods below were used for both soil and DSS samples. $\mathrm{pH}$ was measured by the electrometric method from a soil extract in $\mathrm{KCl}(10 \mathrm{~g}$ of soil in $25 \mathrm{ml}$ of $\mathrm{KCl})$. Total $\mathrm{N}$ was measured by the Kjeldahl method, the total organic carbon $\left(\mathrm{C}_{\text {org }}\right)$ was determined using the Tiurin method, total phosphorus by the flow spectrophotometric method (SKALAR San System) and total potassium by the flame emission spectrometry method (AAS-3 Carl Zeiss Jena) after wet sulphuric acid digestion of samples. Heavy metals were extracted with aqua regia and measured with atomic absorption spectroscopy (AAS). For N, C and P determination, we used dried soil $\left(105^{\circ} \mathrm{C}\right)$.

\section{Microbial activity}

Dehydrogenase activity was measured in a Tris- $\mathrm{HCl}$ buffer (pH 7.4) with triphenyl tetrazolium chloride (TTC) as a substrate following Thalmann (1968). Enzymatic activity 
was determined with a spectrophotometer at $485 \mathrm{~nm}$, with methanol as a reference. The respiratory activity was determined by substrate-induced method in accordance with Rühling and Tyler (1973) in $20 \mathrm{~g}$ of soil sample with addition of $10 \mathrm{mg}$ glucose $\mathrm{g}^{-1}$ dry soil. $\mathrm{CO}_{2}$ released from soil was used to calculate respiratory activity.

\section{Community-level physiological profiling (CLPP) analysis}

The Biolog EcoPlate contains 31 different carbon sources and a control well with water, each in triplicate. Tetrazolium violet redox dye was used for each well as a colour indicator to evaluate whether microorganisms used the substrates (Insam and Goberna 2004). One gram of fresh soil was shaken in $99 \mathrm{ml}$ of distilled sterile water for $20 \mathrm{~min}$ at $20{ }^{\circ} \mathrm{C}$ and then incubated at $4{ }^{\circ} \mathrm{C}$ for 30 min (Pohland and Owen 2009). Next, $120 \mu \mathrm{l}$ of each sample was inoculated into each well of Biolog EcoPlates and incubated at $25{ }^{\circ} \mathrm{C}$ for 5 days. The utilisation rate was evaluated on reduction of the redox indicator dye (tetrazolium), which changes from colourless to purple (Islam et al. 2011). Microplate station was used to read the absorbance values at $590 \mathrm{~nm}$ every $24 \mathrm{~h}$ through 5 days. Plate readings at $48 \mathrm{~h}$ of incubation were used to calculate AWCD, R and $\mathrm{H}$ because it was the shortest incubation time of incubation that allowed good resolution among the treatments. Microbial response in each microplate expressed as average well colour development (AWCD) was determined according to Gomez et al. (2006): $\mathrm{AWCD}=\Sigma \mathrm{OD}_{\mathrm{i}} / 3$, where ODi is the optical density value from each well, corrected by subtracting the blank well values from each plate well (Weber et al. 2007). Richness (R) values were calculated as the number of oxidised $\mathrm{C}$ substrates, and the Shannon-Weaver index values (H) (i.e. the richness and evenness of response) were calculated using an OD of 0.25 as the threshold for a positive response. The Shannon-Weaver index was calculated as follows: $H=-\Sigma p_{i}$ (lnpi), where $p_{i}$ is the ratio of the activity on each substrate (ODi) to the sum of activities on all substrates $\Sigma O D i$. To evaluate results, we used the five carbon substrate guilds: (1) carbohydrates, (2) carboxylic and acetic acids, (3) amino acids, (4) polymers and (5) amines and amides according to Weber and Legge (2009).

\section{Stratification and rhizosphere ratios}

Stratification ratios were calculated by dividing the soil microbe properties at $0-20 \mathrm{~cm}$ by those at $25-30 \mathrm{~cm}$. Rhizosphere ratios were calculated by dividing microbial properties in the rhizosphere by those in adjacent (nonrhizosphere) at $0-20 \mathrm{~cm}$.

\section{Statistical analysis}

All statistical analyses were performed using Statistica 9.0 software (2010). AWCD, R and Shannon-Weaver indices, dehydrogenase and respiratory activity were investigated by analysis of variance (two-way ANOVA) following the data set test on normal distribution. Layer and fertiliser treatment were used as independent factors for ANOVA. Comparisons between treatments were performed using Tukey's post hoc honestly significant differences (HSD) at $P<0.05,0.01$ or 0.001 . A principal component analysis (PCA) was performed and Pearson's correlation coefficient (R) measured for normalised and transformed absorbance data for each well according to Weber et al. (2007). The transformed data were used for PCA because the two fundamental assumptions of the PCA, normality and homoscedasticity, were not met. The normality of the data was evaluated though formal statistical Shapiro-Wilk tests. Homoscedasticity, which is homogeneity of variance, was evaluated with a Hartley test.

\section{Results and discussion}

Live plants and crop residues are the major source of carbon for soil microbiota. As shown in our study, the microbial activity as determined by both enzyme activity and indices of the diversity in catabolic potential can be stimulated by carbon input using DSS. As seen from Figs. 1 and 2, dehydrogenase (ADh) and respiratory (RESP) activities reached the maximum in the DSS treatment and the minimum in the control group. Significant differences $(P<0.05)$ for dehydrogenase activity occurred between DSS and the control in the surface non-rhizosphere soil $(>120 \%)$. Respiratory activity behaved the same way with respect to the DSS treatment and the control in surface rhizosphere soil and subsurface non-rhizosphere soil. However, there were no significant differences in either microbial activity parameter between DSS and MF. For all comparable treatments (C, DSS and MF), dehydrogenase activity and respiratory activity decreased in the following order: surface rhizosphere soil, surface non-rhizosphere soil and subsurface non-rhizosphere soil. The most pronounced decline occurred in the dehydrogenase activity of the subsurface non-rhizosphere soil $(\sim 80 \%)$. This effect was caused because of the additional carbon supply originating from root exudates. It is worth noting that in our experiment, organic amendment served as an easily accessible soil carbon source for microorganisms, even a year after its application.

The diversity in catabolic potential as expressed by CLPP indices showed that the introduction of DSS and MF into soil increased the AWCD and R in surface rhizosphere 


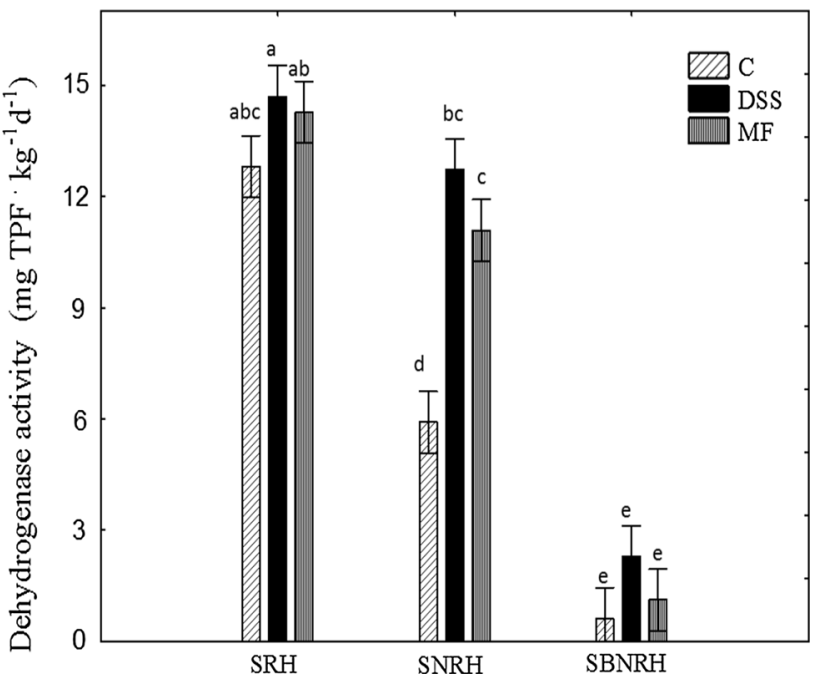

Fig. 1 Mean values of dehydrogenase activity as influenced by amendment treatments and soil layer. Different letters within the same variable (layer) indicate significant differences between the treatments. $(P<0.05)$; standard error bars with $n=3$. $C$ control soil, $M F$ mineral fertilised soil, DSS dairy sewage sludge-amended soil, SNRH surface non-rhizosphere soil layer $(0-20 \mathrm{~cm}), S R H$ surface rhizosphere soil layer $(0-20 \mathrm{~cm}), S B N R H$ subsurface non-rhizosphere soil layer $(25-30 \mathrm{~cm})$

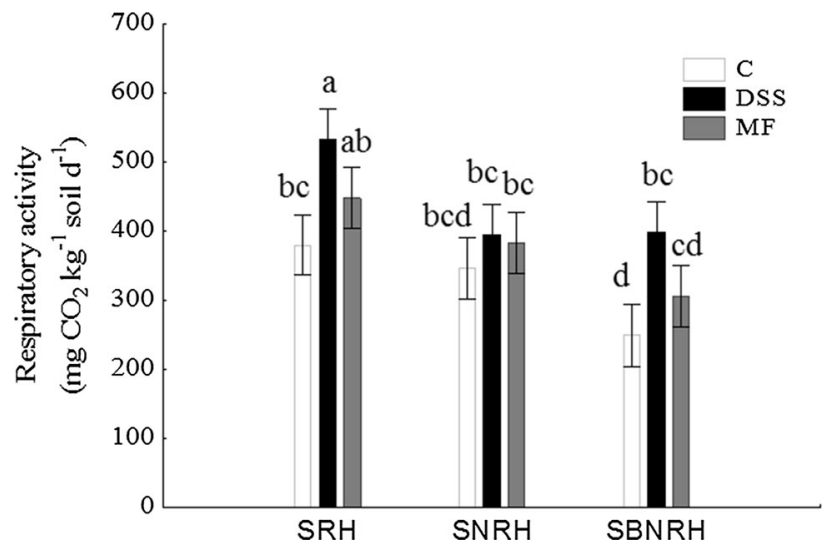

Fig. 2 Mean values of respiratory activity as influenced by amendment treatments and soil layer. Different letters within the same variable (layer) indicate significant differences between the treatments. $(P<0.05)$; standard error bars with $n=3$. $C$ control soil, $M F$ mineral fertilised soil, DSS dairy sewage sludge-amended soil, $S N R H$ surface non-rhizosphere soil layer $(0-20 \mathrm{~cm}), S R H$ surface rhizosphere soil layer $(0-20 \mathrm{~cm}), S B N R H$ subsurface non-rhizosphere soil layer $(25-30 \mathrm{~cm})$

(Fig. 3a) and surface non-rhizosphere soil (Fig. 3b). These differences were most evident in surface rhizosphere soil. AWCD and R values were the most pronounced under the DSS $(P<0.05)$ treatment. This agrees with the substantially greater soil organic carbon content in the DSS treatment (Table 1). These results are consistent with those of Gomez et al. (2006), who noticed significant increases in AWCD, R and $\mathrm{H}$ several months after sludge application.
However, in surface non-rhizosphere soil, the maximum values of both microbial indices were greater in the MF treatment $(P<0.05)$ than in control soil, as measured by AWCD and R. In subsurface non-rhizosphere soil, these indices were not different $(P<0.05)$ among the treatments. There were no differences among treatments or sampling areas according to the Shannon-Weaver index $(P<0.05)$.

Nearly all of the subject parameters were significantly positively correlated with each other (Table 2). It is worth noting that AWCD, ADh and RESP were significantly $(\alpha=0.001)$ correlated with $C_{\text {org }}$ (Table 2). The rhizosphere ratios and stratification ratios were significantly influenced by DSS and mineral fertilisers (MF) only with respect to ADh (Table 3). The rhizosphere ratio was reduced by DSS and MF versus the control, and the stratification ratio was lowest with DSS. Ratios for the remaining microbial parameters did not differ significantly among the treatments.

To determine the differences in carbon source catabolism among treatments, a PCA was performed. The first and second principal component (PC1 and $\mathrm{PC} 2)$ in surface rhizosphere soil explained 27.91 and $19.59 \%$ of the data variance, respectively (Table 4). The two carbon sources with the highest positive loadings in PC1 and PC2 under SRH were D-xylose (0.93) and $\alpha$-cyclodextrin (0.82). In the non-rhizosphere soil, PC1 and PC2 explained 31.30 and $21.06 \%$ of the variability in the data. The corresponding values in subsurface non-rhizosphere soil were 35.42 and $21.79 \%$. In surface non-rhizosphere soil, the highest positive loading for PC1 was from $\mathrm{N}$-acetyl-D-glucosamine (0.86) and for PC2 it was negative erythritol $(-0.96)$. In the subsurface non-rhizosphere soil, the highest loading in PC1 was from putrescine $(0.90)$ and from L-serine $(-0.89)$ in PC2.

As it can be seen from Fig. 4, the proportions of carbon source utilisation differ within treatments and sampling areas. Microbial utilisation of carbohydrates and polymers was greater under DSS and MF in surface (more by 11 and $10 \%$ for carbohydrates, respectively, and more by 2 and $3 \%$ for polymers, respectively) and subsurface non-rhizosphere soils and under DSS in surface rhizosphere, compared to the control (2 and $3 \%$, respectively, for carbohydrates and polymers). This increase was primarily at the expense of amines and amides under DSS and of amino acids under MF. Irrespective of treatment and sampling area, the utilisation of carboxylic and acetic acid was similar.

A relatively long-lasting positive effect of DSS on microbial activity can be associated with the mixing of the organic fraction and fine mineral soil particles and also with the formation of organic-matter-rich aggregates that can physically protect organic matter (OM) from 
(a)
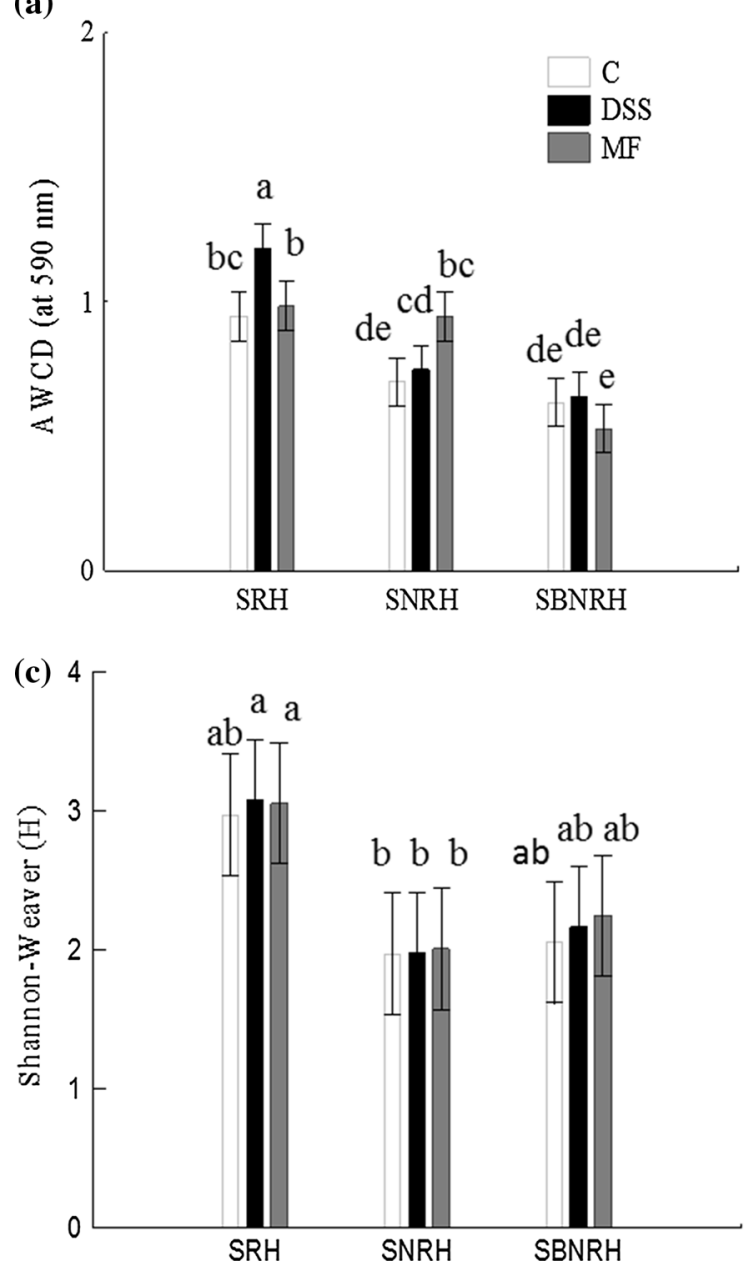

Fig. 3 Mean values of microbial functionality ( $A W C D$ average well colour development, $R$ richness, $H$ Shannon-Weaver index) as influenced by amendment treatments and soil layer. Different letters within the same variable indicate significant differences $(P<0.05)$;

decomposition (Six et al. 2002; Król et al. 2013). Among the mechanisms proposed to explain the phenomena of this physical protection of $\mathrm{OM}$ in soil are the adsorption of organic molecules onto inorganic clay surfaces and the entrapment of organic material in soil microaggregates and their biochemical stabilisation through the formation of recalcitrant OM compounds (McCarthy et al. 2008; Wiesmeier et al. 2012). At the same time, preservation of biological carbon and nitrogen from DSS leads to the formation of binding agents that cement soil particles and thereby increase soil aggregation stability (De Moraes and Lal 2009; Wiesmeier et al. 2012).

Typically, the occurrence of microorganisms depends on the presence of organic carbon and decreases with depth in the soil profile. However, we observed that the organic carbon content in the subsurface layer of soil that was amended with the DSS was equal to the content of the surface layer (Table 1). Organic carbon might have been

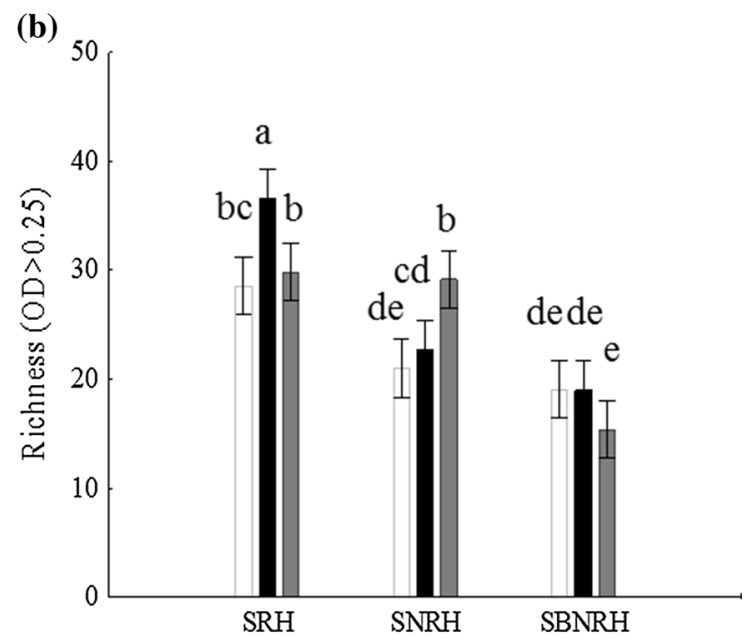

$n=3$. $C$ control soil, $M F$ mineral fertilised soil, $D S S$ dairy sewage sludge-amended soil, $S N R H$ surface non-rhizosphere soil layer $(0-20 \mathrm{~cm}), S R H$ surface rhizosphere soil layer $(0-20 \mathrm{~cm}), S B N R H$ subsurface non-rhizosphere soil layer $(25-30 \mathrm{~cm})$

enhanced by inverting and mixing the soil by ploughing shortly after the surface DSS application.

These findings indicate that tillage can incorporate DSS organic amendments that were applied to the surface into the deeper soil layers and thus expand the depth of microbial activity, as indicated by enhanced respiratory activity. These results partially support the hypothesis of this study. Our results are consistent with findings of Treonis et al. (2010) and Gajda and Przewłoka (2012), showing that organic amendment can stimulate biological activity when soil is inverted by ploughing. Although organic waste such as DSS is a valuable source of organic carbon for microorganisms and nitrogen for plants, it may also increase the potential of nutrient leaching to deeper soil layers. However, the turnover of bound nitrogen by decomposers can be of fundamental importance for increasing the fertilisation effect and decreasing $\mathrm{N}$ leaching (Lipiec et al. 2011). The upswing of microbial activity in surface and 
subsurface soil with added DSS may have had a positive impact on rape seed yield, which was approximately $30 \%$ higher compared to plants grown in the control plots.

Table 1 Soil $\mathrm{C}_{\text {org }}$ and $\mathrm{N}_{\text {tot }}$ content under particular amendment in soil layers

\begin{tabular}{lllr}
\hline Treatments & $\begin{array}{l}\mathrm{C}_{\text {org }} \\
\left(\mathrm{g} \mathrm{kg}^{-1} \text { d.m. soil }\right)\end{array}$ & $\begin{array}{l}\mathrm{N}_{\text {tot }} \\
\left(\mathrm{g} \mathrm{kg}^{-1} \text { d.m. soil }\right)\end{array}$ & $\mathrm{C}_{\text {org }}: \mathrm{N}_{\text {tot }}$ \\
\hline \multicolumn{2}{l}{ Surface rhizosphere soil } & & \\
DSS & 16.04 & 1.09 & 14.66 \\
MF & 14.17 & 0.90 & 15.65 \\
C & 10.82 & 0.78 & 13.94 \\
Surface & non-rhizosphere soil & & \\
DSS & 13.09 & 1.31 & 9.97 \\
MF & 12.31 & 1.24 & 9.91 \\
C & 11.63 & 1.12 & 10.35 \\
Subsurface & non-rhizosphere soil & & 16.06 \\
DSS & 13.92 & 0.87 & 8.92 \\
MF & 6.92 & 0.78 & 6.57 \\
C & 6.61 & 1.01 & \\
\hline
\end{tabular}

DSS dairy sewage sludge-amended soil, $M F$ mineral fertilised soil, $C$ control soil, $n=3$
Continuing our experiment may elucidate the effects of DSS on crop yield.

In this study, we explored whether the microbial diversity in catabolic potential and soil dehydrogenase and respiratory activity were sensitive enough to assess which fertiliser substantially improved the soil status. This study is part of an effort to better understand how DSS affects the vertical distribution and organisation of soil microbes in particular depths of the terrestrial soil profile.

\section{Conclusion}

Regarding all the positions and motivations of the DSS agricultural use as the most advantageous route, comparing to mineral fertilising (MF), we highlighted the need to improve soil management practices and to focus deeper on considering the fact that soil have to be monitored properly to show any effect occurring after DSS application. The stratification indices were therefore proposed for a soil differently fertilised to be compared on the same assessment scales decently. Results showed that the soil microbial functionality under winter rape was the highest under DSS application and the lowest under control. For all
Table 2 Pearson correlation coefficients $(r)$ for microbial properties, $\mathrm{C}_{\text {org }}$ and $\mathrm{N}_{\text {tot }}$ content in soil treated with mineral fertilisers and dairy sewage sludge

\begin{tabular}{|c|c|c|c|c|c|c|}
\hline Dependent variable & $\mathrm{R}$ & AWCD & $\mathrm{H}$ & $\mathrm{ADh}$ & RESP & $\mathrm{C}_{\text {org }}$ \\
\hline AWCD & $0.388^{*}$ & & & & & \\
\hline $\mathrm{H}$ & $0.526 * *$ & $0.466^{*}$ & & & & \\
\hline $\mathrm{ADh}\left(\mathrm{mg}\right.$ TPF $\left.\mathrm{kg}^{-1} \mathrm{~d}^{-1}\right)$ & $0.482 *$ & $0.802 * * *$ & $0.513 * *$ & & & \\
\hline $\operatorname{RESP}\left(\mathrm{mg} \mathrm{CO} \mathrm{kg}^{-1} \mathrm{~d}^{-1}\right)$ & $0.495^{* *}$ & $0.654 * * *$ & $0.577 * *$ & $0.719 * * *$ & & \\
\hline $\mathrm{C}_{\mathrm{org}}\left(\mathrm{g} \mathrm{kg}^{-1}\right.$ d.m. soil $)$ & 0.220 & $0.707 * * *$ & -0.169 & $0.706 * * *$ & $0.864 * * *$ & \\
\hline $\mathrm{N}_{\text {tot }}\left(\mathrm{g} \mathrm{kg}^{-1}\right.$ d.m. soil $)$ & -0.451 & 0.492 & 0.011 & -0.313 & -0.441 & -0.343 \\
\hline
\end{tabular}

$N S$ not significant correlation, $A W C D$ average well colour development, $R$ richness index, $H$ ShannonWeaver index, $A D h$ dehydrogenase activity, RESP respiratory activity

$*, * *$ and $* * *$ represent statistical significance at $0.05,0.01$ and 0.001 level, respectively

\begin{tabular}{|c|c|c|c|c|c|c|}
\hline \multirow[t]{2}{*}{ Dependent variable } & \multicolumn{3}{|c|}{ Rhizosphere ratio $^{1}$} & \multicolumn{3}{|c|}{ Stratification ratio $^{2}$} \\
\hline & DSS & $\mathrm{MF}$ & $\mathrm{C}$ & DSS & MF & $\mathrm{C}$ \\
\hline Dehydrogenase activity & $1.16 \mathrm{~b}$ & $1.29 \mathrm{~b}$ & $2.25 \mathrm{a}$ & $5.57 \mathrm{~b}$ & $9.95 \mathrm{a}$ & $9.77 \mathrm{a}$ \\
\hline Respiratory activity & $1.37 \mathrm{a}$ & $1.18 \mathrm{a}$ & $1.11 \mathrm{a}$ & $0.99 \mathrm{a}$ & $1.29 \mathrm{a}$ & $1.52 \mathrm{a}$ \\
\hline Average well colour development & $1.36 \mathrm{a}$ & $1.06 \mathrm{a}$ & $1.61 \mathrm{a}$ & $1.12 \mathrm{a}$ & $2.66 \mathrm{a}$ & $1.16 \mathrm{a}$ \\
\hline Richness index & $1.37 \mathrm{a}$ & $1.43 \mathrm{a}$ & $1.61 \mathrm{a}$ & $1.11 \mathrm{a}$ & $1.10 \mathrm{a}$ & $1.20 \mathrm{a}$ \\
\hline Shannon-Weaver index & $1.56 \mathrm{a}$ & $1.56 \mathrm{a}$ & $1.62 \mathrm{a}$ & $1.03 \mathrm{a}$ & $0.92 \mathrm{a}$ & $0.95 \mathrm{a}$ \\
\hline
\end{tabular}

Different letters show significant differences $(P<0.05)$ between treatments for each parameter; $n=3$

DSS, $M F$ and $C$ represent dairy sewage sludge-amended soil, mineral fertilised soil and control soil, respectively

${ }^{1}$ Rhizosphere ratio includes treatments from surface $(0-20 \mathrm{~cm})$ associated and not associated with roots

${ }^{2}$ Stratification ratio includes non-rhizosphere treatments from surface $(0-20 \mathrm{~cm})$ and subsurface $(25-30 \mathrm{~cm})$ 
Table 4 Most discriminant carbon substrates as determined by principal component analysis on the data of community-level carbon source utilisation using Biolog EcoPlates in soil treated with dairy sewage sludge $(\mathrm{R}>0.7)$ showing the factor loadings for the CLPP data

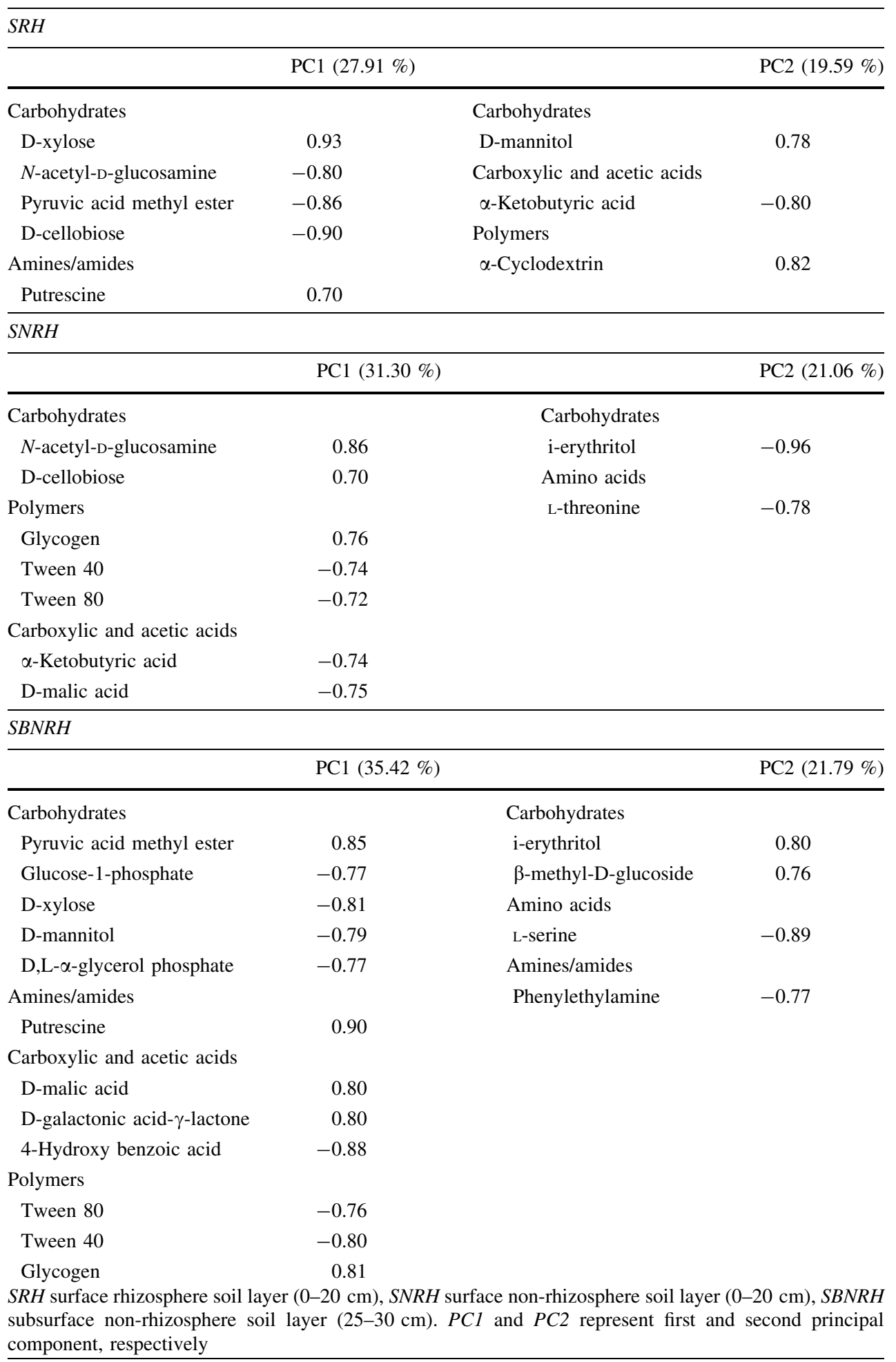

treatments, the dehydrogenases and respiratory activities decreased from the surface rhizosphere to surface nonrhizosphere to subsurface non-rhizosphere soils. Our results proved that microbial activity and the diversity in catabolic potential were stratified in the soil profile as a result of soil organic $\mathrm{C}$ content which was controlled by the DSS application in combination with ploughing. This response indicated improvement of organic matter balance in soil, what is in repercussion essential in soil quality evaluation after organic amendments application. 


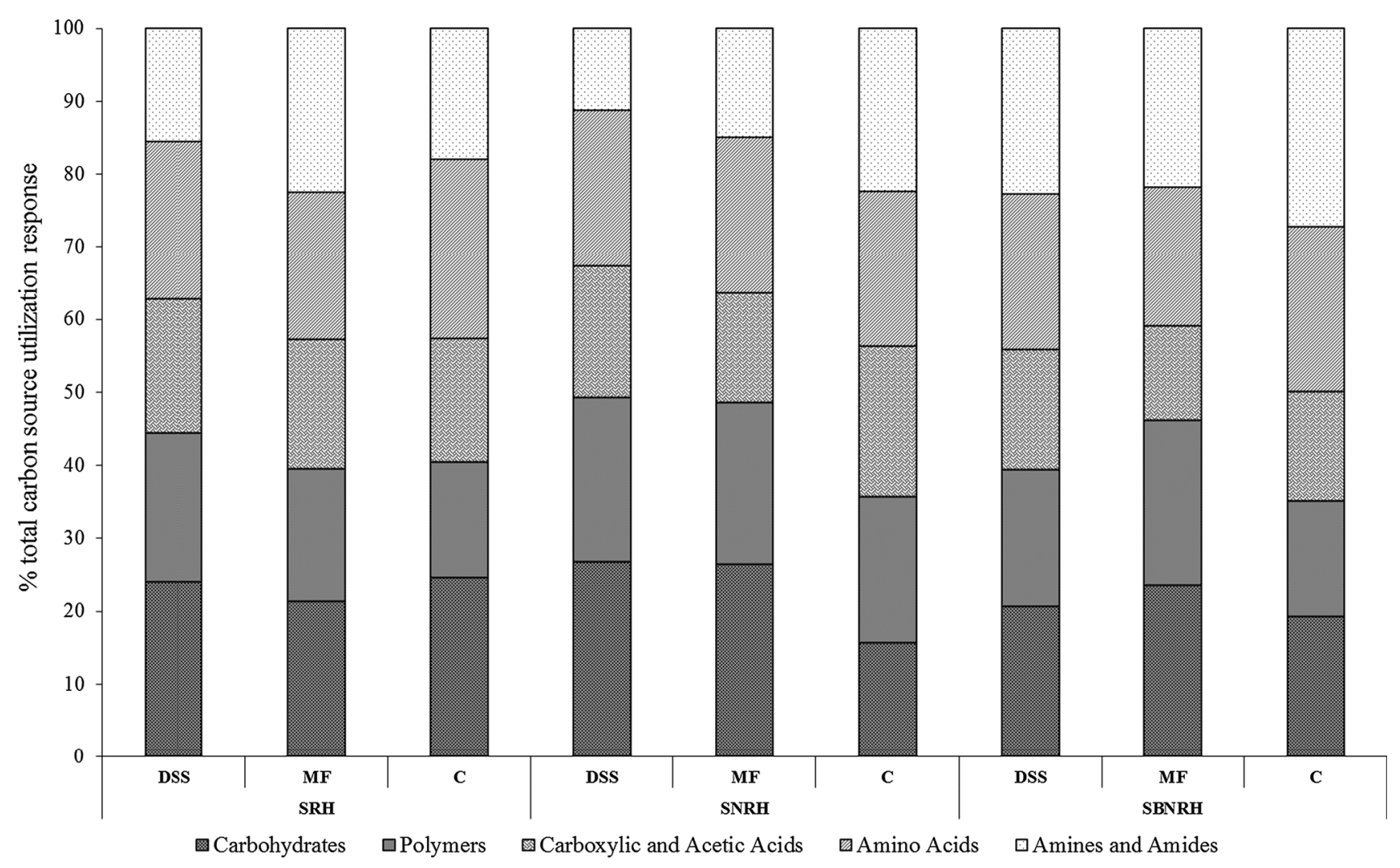

Fig. 4 Proportion of total carbon source utilisation response tracked due to treatment type, for the different guilds. $C$ control soil, $M F$ mineral fertilised soil, DSS dairy sewage sludge-amended soil, SNRH

Acknowledgments The research was partially funded by funds from the Ministry of Science and Higher Education in Poland in the years 2010-2013 as a research project (N N310 307439). The analyses were performed using equipment bought with European Union funds under the Eastern Poland Development Programme Regional Laboratory of Renewable Energy.

Open Access This article is distributed under the terms of the Creative Commons Attribution License which permits any use, distribution, and reproduction in any medium, provided the original author(s) and the source are credited.

\section{References}

Antonijević MM, Marić M (2008) Determination of the content of heavy metals in pyrite contaminated soil and plants. Sensors 8:5857-5865

Ascher J, Ceccherini MT, Landi L, Mench M, Pietramellara G, Nannipieri P, Renella G (2009) Composition, biomass and activity of microflora, and leaf yields and foliar elemental concentrations of lettuce, after in situ stabilization of an arseniccontaminated soil. Appl Soil Ecol 41:351-359

Bieganowski A, Łagód G, Ryżak M, Montusiewicz A, Chomczyńska M, Sochan A (2012) Measurement of activated sludge particle diameters using laser diffraction method. Ecol Chem Eng 19:597-608

Chaparro JM, Sheflin AM, Manter DK, Vivanco JM (2012) Manipulating the soil microbiome to increase soil health and plant fertility. Biol Fertil Soils 48:489-499 surface non-rhizosphere soil layer $(0-20 \mathrm{~cm})$, SRH surface rhizosphere soil layer $(0-20 \mathrm{~cm}), S B N R H$ subsurface non-rhizosphere soil layer $(25-30 \mathrm{~cm})$

Chen H, Yan SH, Ye ZL, Meng HJ, Zhu YG (2012) Utilization of urban sewage sludge: Chinese perspectives. Environ Sci Pollut Res 19:1454-1463

De Moraes Sa JC, Lal R (2009) Stratification ratio of soil organic matter pools as an indicator of carbon sequestration in tillage chronosequence on Brazilian Oxisol. Soil Tillage Res 103:46-56

Diacono M, Montemurro F (2010) Long-term effects of organic amendments on soil fertility - a review. Agron Sustain Dev 30:401-422

Ettema CH, Wardle DA (2002) Spatial soil ecology. Trends Ecol Evol 17:177-183

Frąc M (2012) Mycological evaluation of dairy sewage sludge and its influence on functional diversity of soil microorganisms. Acta Agrophys Monogr 1:50-120

Frąc M, Jezierska-Tys S (2011) Agricultural utilization of dairy sewage sludge: its effect on enzymatic activity and microorganisms of the soil environment. Afr J Microbiol Res 5:1755-1762

Frąc M, Oszust K, Lipiec J (2012) Community level physiological profiles characterization and microbial activity of soil amended with dairy sewage sludge. Sensors 12:3253-3268

Franzluebbers AJ (2002) Soil organic matter stratification ratio as an indicator of soil quality. Soil Tillage Res 66:95-101

Gajda AM, Przewłoka B (2012) Soil biological activity as affected by tillage intensity. Int Agrophys 26:15-23

Gomez E, Garland J, Conti M (2004) Reproducibility in the response of soil bacterial community-level physiological profiles from a land use intensification gradient. Appl Soil Ecol 26:21-30

Gomez E, Ferreras L, Toresani S (2006) Soil bacterial functional diversity as influenced by organic amendment application. Bioresour Technol 97:1484-1489 
Gryta A, Frąc M, Oszust K (2014) The application of the biolog ecoplate approach in ecotoxicological evaluation of dairy sewage sludge. Appl Biochem Biotechnol 174:1434-1443

Insam H, Goberna M (2004) Use of Biolog ${ }^{\circledR}$ for community level physiological profiling (CLPP) of environmental samples. In: Kowalchuk GA, de Bruijn FJ, Head IM, Akkermans AD, van Elsas JD (eds) Molecular microbial ecology manual. Kluwer Academic, Dordrecht, pp 853-860

Islam R, Chauhan PS, Kim Y, Kim M, Sa T (2011) Community level functional diversity and enzyme activities in paddy soils under different long-term fertilizer management practices. Biol Fertil Soils 47:599-604

Jezierska-Tys S, Frąc M (2009) Impact of dairy sewage sludge on enzymatic activity and inorganic nitrogen concentrations in the soils. Int Agrophys 23(1):31-37

Khaliq A, Abbasi KM, Hussain T (2006) Effects of integrated use of organic and inorganic nutrient sources with effective microorganisms (EM) on seed cotton yield in Pakistan. Bioresour Technol 97:967-972

Król A, Lipiec J, Turski M, Kuś J (2013) Effects of organic and conventional management on physical properties of soil aggregates. Int Agrophys 27:15-21

Lal R (2009) Laws of sustainable management. Agron Sunstain Dev 29:7-9

Lipiec J, Nosalewicz A, Siczek A, Kotowska U (2011) Effects of land use on leaching of nitrate- $\mathrm{N}$, ammonium- $\mathrm{N}$ and phosphate in relation to stained surface area. Int Agrophys 25(2):149-154

McCarthy JF, Ilavsky J, Mayer LM, Perfekt E, Zhuang J (2008) Protection of organic carbon soil microaggregates occur via restructuring of aggregate porosity and filling pores with accumulating organic matter. Geochim Cosmochim Acta $74: 725-4744$

Mikosz J (2014) Determination of permissible industrial pollution load at a municipal wastewater treatment plant. Int J Environ Sci Technol. doi:10.1007/s13762-013-0472-0

Murugan R, Loges R, Taube F, Sradnick A, Joergensen RG (2014) Changes in soil microbial biomass and residual indices as ecological indicators of land use change in temperate permanent grassland. Microb Ecol 67(4):907-918

Oszust K, Frąc M, Gryta A, Bilińska N (2014) The influence of ecological and conventional plant production systems on soil microbial quality under hops (Humulus lupulus). Int J Mol Sci 15:9907-9923

Pascual I, Avilés M, Aguirreolea J, Sánchez-Diaz M (2008) Effect of sanitized and nonsanitized sewage sludge on soil microbial community and the physiology of pepper plants. Plant Soil 310:41-53

Pohland B, Owen B (2009) Biolog EcoPlates standard methods. TAS Technical Biul Biolog, Hayward, pp 1-3
Qin Z, Xie J, Quan G, Zhang J, Mao D, Di Tommaso A (2014) Impacts of the invasive annual herb Ambrosia artemisiifolia $\mathrm{L}$. on soil microbial carbon source utilization and enzymatic activities. Eur J Soil Biol 60:58-66

Raynaud X, Nunan N (2014) Spatial ecology of bacteria at the microscale in soil. PLoS One 9(1):e87217. doi:10.1371/journal. pone. 0087217

Rühling A, Tyler G (1973) Heavy metal pollution and decomposition of spruce needy litter. Oikos 24:402-415

Schimel JP, Schaeffer SM (2012) Microbial control over carbon cycling in soil. Front Microbiol 3:348

Schutter M, Dick R (2001) Shifts in substrate utilization potential and structure of soil microbial communities in response to carbon substrates. Soil Biol Biochem 33:1481-1491

Singh RP, Agrawal M (2008) Potential benefits and risks of land application of sewage sludge. Waste Manag 28:347-358

Six J, Feller C, Denef K, Ogle SM (2002) Soil organic matter, biota and aggregation in temperate and tropical soils-effect of notillage. Agronomie 22:755-775

Thalmann A (1968) Zur methodik der Bestimmung der Dehydrogenase activität im Boden Mittels Triphenyltetrazoliumchlorid (TTC). Landwirtsh Forsch 21:249-258

Treonis AM, Austin EE, Buyer JS, Maul JE, Spicer L, Zasada IA (2010) Effects of organic amendment and tillage on soil microorganisms and microfauna. Appl Soil Ecol 46:103-110

Wang X, Chen T, Ge Y, Jia Y (2008) Studies on land application of sewage sludge and its limiting factors. J Hazard Mater 160:554-558

Weber K, Legge R (2009) One-dimensional metric for tracking bacterial community divergence using sole carbon source utilization patterns. J Microbiol Methods 79:55-61

Weber P, Grove J, Gehder M, Anderson W, Legge R (2007) Data transformations in the analysis of community-level substrate utilization data from microplates. J Microbiol Methods 79:461-469

Wiesmeier M, Spörlein P, Geuß U, Hangen E, Haug S, Reischl A, Schilling B, von Lützow M, Kögel-Knabner I (2012) Soil organic carbon stocks in southeast Germany (Bavaria) as affected by land use, soil type and sampling depth. Global Change Biol 18:2233-2245

Williams A, Birkhofer K, Hedlund K (2014) Above- and belowground interactions with agricultural management: effects of soil microbial communities on barley and aphids. Pedobiol 57(2):67-74

Zhu L, Dai X, Xu X, Lv M, Cao D (2014) Microbial community analysis for aerobic granular sludge reactor treating high-level 4-chloroaniline wastewater. Int $\mathrm{J}$ Environ Sci Technol 11:1845-1854. doi:10.1007/s13762-013-0380-3 